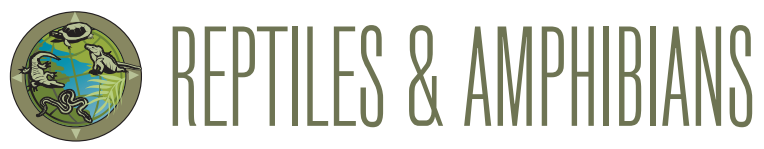

\title{
A Failed Predation Attempt by a Central American Indigo Snake (Drymarchon melanurus) on a Tiger Ratsnake (Spilotes pullatus) in Campeche, Mexico
}

Joseph Oakley and Alexandros Theodorou

Operation Wallacea, Wallace House, Old Bolingbroke, Lincolnshire, PE23 4EX, UK (josephoakley94@gmail.com)

$\mathrm{T}$ The Central American Indigo Snake (Drymarchon melanurus) is a large snake that inhabits forests, savannas, grasslands, and mangroves from the southern United States through Mexico and Central America to northwestern South America (Lee 2000; Wüster et al. 2001). It is a diurnally active, primarily terrestrial species with a varied diet comprised of small mammals, birds, bird eggs, fish, anurans, lizards, and especially snakes (Hardy and McDiarmid 1969; LemosEspinal and Dixon 2013; Platt et al. 2016). Previous accounts (Daza-R. 2005; Hernández-Ríos et al. 2013) have documented individuals ingesting or attempting to ingest snakes of similar size. The Tiger Ratsnake (Spilotes pullatus), another large diurnally active snake that inhabits forests, savannas, and mangroves from Mexico south to South America, co-occurs with D. melanurus across parts of its range (Lee 2000).

At 1112 h on 3 July 2019, during a herpetological transect survey in tropical semi-deciduous forest in the buffer zone of the Calakmul Biosphere Reserve in Campeche, Mexico $\left(18.81609^{\circ} \mathrm{N}, 89.27442^{\circ} \mathrm{W}\right.$; WGS 84; elev. $178 \mathrm{~m}$ asl), we encountered an adult $D$. melanurus biting the tail of an adult S. pullatus of comparable size (Fig. 1). The Central American Indigo Snake was twisting its head and adjusting its grip while the Tiger Ratsnake struggled. After approximately $45 \mathrm{sec}$, the S. pullatus managed to escape and fled, closely pursued by the D. melanurus. We attempted to follow the snakes but found no further signs of them.

Previously, Hernández-Ríos et al. (2013) observed a D. melanurus in the process of consuming a $S$. pullatus in the state of Tamaulipas, Mexico, although the prey was subsequently regurgitated; however, because initial capture of the prey was not observed, whether the $S$. pullatus was predated or scavenged is unknown. Our observation provides definitive evidence that $D$. melanurus actively hunts $S$. pullatus. Due to an overlapping distribution, similar habitat preferences of both species, and a tendency for D. melanurus to prey on snakes, this type of interaction likely occurs with some regularity. However, successful predation and consumption of $S$. pullatus by $D$. melanurus has yet to be documented.

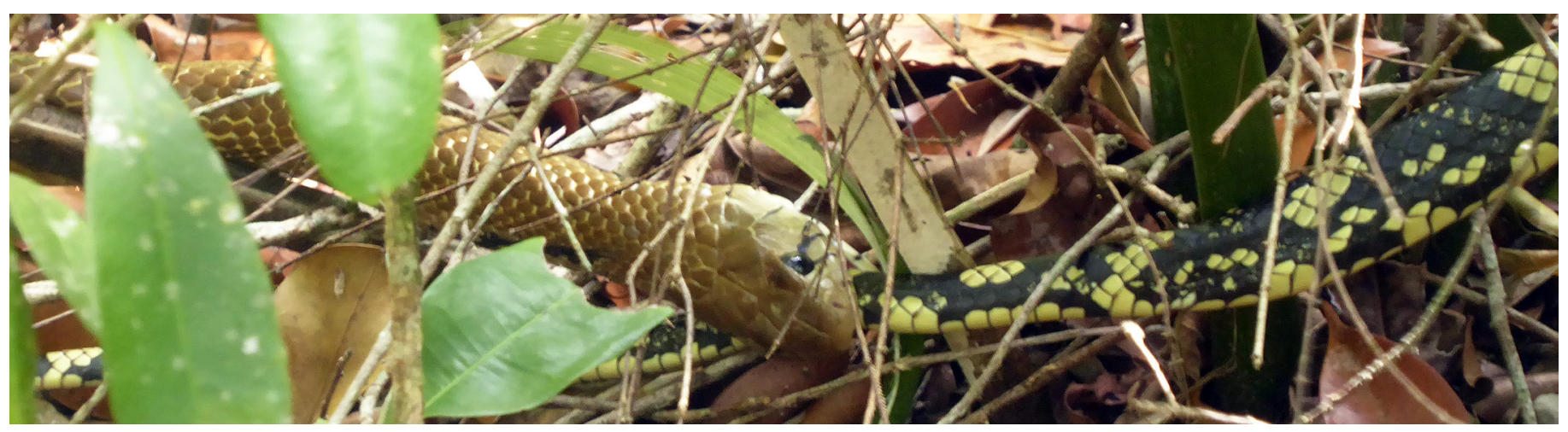

Fig. 1. A Central American Indigo Snake (Drymarchon melanurus) attempting to prey on a Tiger Ratsnake (Spilotes pullatus) in Campeche, Mexico. Photograph by Joseph Oakley. 


\section{Acknowledgements}

We thank Operation Wallacea for providing the opportunity to conduct herpetological surveys at the Calakmul site.

\section{Literature Cited}

Daza-R., J.M. 2005. Drymarchon corais melanurus (Indigo Snake). Diet. Herpetological Review 36: 457.

Hardy, L.M. and R.W. McDiarmid. 1969. The amphibians and reptiles of Sinaloa, Mexico. University of Kansas Publications, Museum of Natural History 18: 39-252.

Hernández-Ríos, A., E. García-Padilla, and A. Villegas-Nieto. 2013. Drymarchon melanurus (Central American Indigo Snake). Diet. Herpetological Review 44: 690.

Lee, J.C. 2000. A Field Guide to the Amphibians and Reptiles of the Maya World. Cornell University Press, Ithaca, New York, USA.

Lemos-Espinal, J.A. and J.R. Dixon. 2013. Amphibians and Reptiles of San Luis Potosí. Eagle Mountain Publishing, LC, Eagle Mountain, Utah, USA.

Platt, S.G., T.R. Rainwater, J.C. Meerman, and S.M. Miller. 2016. Notes on the diet, foraging behavior, and venom of some snakes in Belize. Mesoamerican Herpetology 3: 162-170.

Wüster, W., J.L. Yrausquin, and A. Mijares-Urrutia. 2001. A new species of indigo snake from north-western Venezuela (Serpentes: Colubridae: Drymarchon). Herpetological Journal 11: 157-166. 